\title{
Effects of shea butter based diet on hepatic and renal enzymes and plasma lipid profile in albino rats
}

\author{
Malachi Oluwaseyi Israel, Ajayi Olubunmi Bolanle, Akomolafe Seun Funmiola \\ Department of Biochemistry, Faculty of Science, Ekiti State University, Ado-Ekiti, Nigeria
}

Email address:

Malachiseyi@gmail.com (O. I. Malachi),bunmi_dave@yahoo.com (O. B. Ajayi), purosefulseun@yahoo.co.uk (S. F. Akomolafe)

\section{To cite this article:}

Malachi Oluwaseyi Israel, Ajayi Olubunmi Bolanle, Akomolafe Seun Funmiola. Effects of Shea Butter Based Diet on Hepatic and Renal Enzymes and Plasma Lipid Profile in Albino Rats. Advances in Biochemistry. Vol. 2, No. 5, 2014, pp. 80-84. doi: 10.11648/j.ab.20140205.15

\begin{abstract}
The effect of feeding Shea butter based diet on plasma, liver and kidney enzymes as well as the plasma lipid profile was studied. Twenty one weaned male rats weighing $35 \mathrm{~g}$ to $45 \mathrm{~g}$ were divided into three groups: control, test one and test two, each containing seven rats. Control group was given feed containing soya bean oil as lipid source ad libitum. In test groups one and two, Shea butter in 5\% and $15 \%(\mathrm{w} / \mathrm{w})$ respectively, replaced soya bean oil. The feeding lasted for 28 days after which the rats were sacrificed and the plasma as well as tissue samples from liver and kidney were collected. From the plasma, lipid profile; aspartate and alanine aminotransferases, alkaline phosphatase and total protein were assayed. From the tissue samples, aspartate and alanine aminotransferases, alkaline phosphatase and total protein were assayed. Significant decrease $(\mathrm{P}<0.05)$ was observed in the total cholesterol (TC), high density lipoprotein (HDL), low density lipoprotein (LDL) and Triglyceride (TG) upon feeding with Shea butter based diet. Feeding with Shea butter did not pose any threat to hepatic and renal tissues.
\end{abstract}

Keywords: Shea Butter, Renal, Hepatic, Lipid Profile

\section{Introduction}

Shea butter is an off-white or ivory-coloured fat extracted from the nut of African Shea tree (Vitellaria paradoxa formally Butryspermum paradoxum) [1]. Shea tree is a plant that is locally abundant in Nigeria in the derived savannah Zones, particularly near towns and village [2,3]. It is considered a sacred tree by many communities and ethnic groups and plays important roles in religious and cultural ceremonies where it is also believed to have some spiritual protective powers $[4,5]$. Different parts of the plant including leaves, roots, seeds, fruit and stem bark have been used in the treatment of enteric infections such as diarrhea, dysentery, helminthes and other gastrointestinal tract infections, skin diseases and wound infections [6]. Its nut is rich in oil and together with the oil palm serve as sources of edible oil for many households in many parts of the Sahel Africa, particularly Northern Nigeria [3,7].

Shea butter is renowned for its use as a component of cosmetic formulations [8] and as a substitute for Cocoa butter in chocolate industries [9], although the taste is noticeably different [10]. In addition to a stearic and oleic acids rich saponifiable fraction [11], Shea butter contains an unsaponifiable fraction composed of bioactive substances that are responsible for Shea butter's medicinal properties [12]. There are no reports of allergic reaction owing to consumption of Shea butter or its produce $[13,14]$. Shea butter has been appreciated for its hypercholesterolemic actions $[15,16]$. This study however evaluates the effect of dietary consumption of Shea butter on hepatic and renal functions as well as on plasma lipid profile.

\section{Materials and Methods}

\subsection{Sources of Materials}

Weaned male albino rats of four weeks old were obtained from the Animal house unit of the Department of Biochemistry, University of Ilorin, Kwara State, Nigeria. Grower's marsh was a Vital Feed brand of UAC of Nigeria Plc containing $54 \%$ carbohydrate, $10 \%$ protein, $3 \%$ fats, $20 \%$ normal supplement. Soya meal and soya bean oil were products of JOF ideal family farms, Owo, Ondo state, Nigeria. Maize grains (Zea may) purchased from Ado-Ekiti local market, was soaked for 5 days, wet milled, sieved and was sun dried to produce corn starch. The vitamin-mineral mixture is a product of Anglican Nutrition Company, England. Sucrose was purchased from Ado-Ekiti local market. Traditionally, 
extracted Shea butter was purchased from Ogbagi-Akoko, Ondo state, Nigeria.

\subsection{Feeding Regime}

Twenty one male rats weighing $35 \mathrm{~g}$ to $45 \mathrm{~g}$ were selected for the experiment. After seven days of acclimatization with grower's mash, the rats were randomly distributed into three groups and fed ad libitum for twenty eight days with weight gained and field intake monitored.

Table 1. Diet Composition $(\mathrm{g} / \mathrm{kg})$

\begin{tabular}{llll}
\hline & Control (grams) & Group 1 (grams) & Group 2 (grams) \\
\hline Soya mill & 510 & 510 & 510 \\
Corn starch & 290 & 290 & 190 \\
Vitamin-Mineral mixture & 50 & 50 & 50 \\
Sucrose & 100 & 100 & 100 \\
Shea butter & -- & 50 & 150 \\
Soya bean oil & 50 & -- & -- \\
\hline
\end{tabular}

Vitamin-mineral mix composition: vitamin A. 15,000,000, vit b6 2,350mg, vit b12 11,350mg, vit c 100mg, nicotinamide $16,700 \mathrm{mg}$, calcium pantothenate $5,350 \mathrm{mg}$, potassium chloride $87,000 \mathrm{mg}$, sodium sulphate $212,000 \mathrm{mg}$, sodium chloride $50,000 \mathrm{mg}$, magnesium sulphate $12,000 \mathrm{mg}$, copper sulphate $12,000 \mathrm{mg}$, zinc sulphate $12,000 \mathrm{mg}$, manganese sulphate $12,000 \mathrm{mg}$, lysine $\mathrm{HCl} 15,000 \mathrm{mg}$ - methionine $1000 \mathrm{mg}$, exponent Q.S $1000 \mathrm{~g}$.

\subsection{Preparation of Serum and Tissue Homogenate}

At the end of the feeding regime, rats were fasted overnight, anaesthesized and blood samples were collected by cardiac puncture into lithium-heparin bottles. It was centrifuged at 3,000 rpm for 10 minutes and the serum was separated and kept until required for analysis.

The rats were then sacrificed and the kidneys as well as liver was carefully removed, cleaned and homogenized with sucrose $(0.25 \mathrm{M})$ and centrifuged at $1500 \mathrm{rpm}$ for 15 minutes to remove cell debris. The supernatant was kept for analysis.

\subsection{Biochemical Analysis}

Total cholesterol (TC), High density lipoprotein (HDL), low density lipoprotein (LDL) and Triglyceride (TG) were estimated from the plasma. Plasma TC was estimated using Randox laboratory kit based on the enzymatic end point method. The HDL was determined by the method of Steins and Meyer [17]. LDL-Cholesterol was calculated with the Friedewald formula [18]. Total protein (TP), alanine aminotransferase (ALT), aspartate aminotransferase (AST) and alkaline phosphatase (APT) were assayed with colorimetric or enzymatic methods using kits.

\subsection{Statistical Analysis}

The results are expressed as mean \pm S.D. Analysis of variance was used to test for differences in the groups. XLStat was used for statistical analysis of results. Differences were considered to be statistically significant at $\mathrm{P}<0.05$.

\section{Results and Discussion}

Table 2. Feed Intake and Growth Performance of Rats Fed with Butter Based Diet

\begin{tabular}{llll}
\hline & Control & $\mathbf{5 \%}$ Shea butter & $\mathbf{1 5 \%}$ Shea butter \\
\hline $\begin{array}{l}\text { Feed intake per } \\
\text { day (grams) }\end{array}$ & $12.01 \pm 3.24 \mathrm{~b}$ & $13.92 \pm 3.12 \mathrm{a}$ & $12.84 \pm 2.23 \mathrm{~b}$ \\
$\begin{array}{l}\text { Weight gain per } \\
\text { day (grams) }\end{array}$ & $1.61 \pm 0.15 \mathrm{~b}$ & $2.22 \pm 0.23 \mathrm{a}$ & $1.76 \pm 0.20 \mathrm{~b}$ \\
\hline
\end{tabular}

- Values are mean \pm standard deviation
- $\quad$ Mean (s) with the same super script in each row are not significantly different at $5 \%$ level of significance $(\mathrm{P}<0.05)$.

As shown in table 2, rats fed on Shea butter based diet presented a higher feed intake and consequently a better growth performance compared to the control rats fed on soy bean oil. This might be due to preference of Shea butter's flavor relative to soy bean oil's. Elizalde and Sclafani [19] and Ackroff et al [20] also experienced preference of feed due to flavor with rats.

Table 3. Plasma Lipid Profile of Rats Fed with Butter Based Diet

\begin{tabular}{llll}
\hline & Control & $\mathbf{5 \%}$ Shea butter & $\mathbf{1 5 \%}$ Shea butter \\
\hline HDL $(\mathrm{mmol} / \mathrm{L})$ & $0.90 \pm 0.03^{\mathrm{a}}$ & $0.70 \pm 0.10^{\mathrm{b}}$ & $0.55 \pm 0.07^{\mathrm{c}}$ \\
TG $(\mathrm{mmol} / \mathrm{L})$ & $1.20 \pm 0.00^{\mathrm{a}}$ & $0.70 \pm 0.20^{\mathrm{b}}$ & $0.55 \pm 0.07^{\mathrm{b}}$ \\
$\mathrm{LDL}(\mathrm{mmol} / \mathrm{L})$ & $0.80 \pm 0.09^{\mathrm{a}}$ & $0.57 \pm 0.12^{\mathrm{b}}$ & $0.48 \pm 0.07^{\mathrm{c}}$ \\
TC(mmol/L) & $2.50 \pm 0.14^{\mathrm{a}}$ & $1.45 \pm 0.21^{\mathrm{b}}$ & $1.20 \pm 0.30^{\mathrm{b}}$ \\
TC/HDL ratio & $2.78 \pm 0.11^{\mathrm{a}}$ & $2.07 \pm 0.09^{\mathrm{b}}$ & $2.18 \pm 0.08^{\mathrm{b}}$ \\
LDL/HDL ratio & $0.89 \pm 0.02^{\mathrm{a}}$ & $0.81 \pm 0.05^{\mathrm{a}}$ & $0.87 \pm 0.03^{\mathrm{a}}$ \\
\hline
\end{tabular}

- Values are mean \pm standard deviation.

- $\quad$ Mean (s) with the same super script in each row are not significantly different at $5 \%$ level of significance $(\mathrm{P}<0.05)$.

- $\quad$ HDL - high density Lipoprotein, TG - triglyceride, LDL - low Density Lipoprotein and TC - total Cholesterol.

The result presented in Table 3 showed a significant decrease in HDL, TG, LDL and total cholesterol when rats fed with Shea butter were compared with the control. This concurs with the work of Akinwale and co-workers [16]. A 1\% drop in serum cholesterol reduces the risk for Coronary Heart Disease (CHD) by 2\% [21]. Kinosian et al. [22], Panagiotakos et al. [23] and Natarajan et al. [24] have reported that changes in ratios of TC/HDL and LDL/HDL are better predictors of CHD risk reduction than changes in levels. As depicted in Table 3, feeding with Shea butter did alter these ratios in a cardio-protective (decreasing) direction. The hypolipidemic effect of Shea butter has been attributed to the presence of saponins in it [16]. Shea butter has been reported to contain saponin [11,25]. A number of sources have shown that saponins from different sources lower serum cholesterol levels in variety of animals including human subjects [26]. Saponins have been reported to form mixed micelles with cholesterol 
and bile acids in the intestine thereby inhibiting its absorption, increasing its excretion, and indirectly decreasing the cholesterol level in the blood when saponin-rich foods such as soyabean, lucerne and chickpea are consumed [27-29]. Matsuura [30] also reported that saponin reduced more harmful LDL-cholesterol selectively in the serum of rats, gerbils and human. Other suggested mechanisms of antihypercholesterolemic action of saponins include delaying the intestinal absorption of dietary fat by inhibiting pancreatic lipase activity [31]. The antihypercholesterolemic effect might also be in part due to Linoleic acid which has been reported to be present in Shea butter [32]. Linoleic acid has been reported to possess a pronounced hypocholesterolemic effect [33, 34]. It is therefore possible that the cumulative effect of long term consumption of Shea butter could prove cardio-protective and help lower coronary heart disease.

Table 4. Plasma, Hepatic and Renal Enzyme Activities of Rats Fed with Butter Based Diet

\begin{tabular}{|c|c|c|c|c|}
\hline & & Control & $5 \%$ Shea butter & $15 \%$ Shea butter \\
\hline \multirow[t]{4}{*}{ Plasma } & ALT(U/L) & $4.00 \pm 0.00^{\mathrm{b}}$ & $8.00 \pm 0.00^{\mathrm{a}}$ & $9.00 \pm 0.00^{\mathrm{a}}$ \\
\hline & AST (U/L) & $44.00 \pm 4.24^{\mathrm{a}}$ & $33.50 \pm 3.54^{b}$ & $33.00 \pm 5.90^{\mathrm{b}}$ \\
\hline & $\operatorname{ALP}(\mathrm{U} / \mathrm{L})$ & $427.88 \pm 16.89^{\mathrm{a}}$ & $153.10 \pm 5.00^{\mathrm{b}}$ & $235.50 \pm 3.54^{b}$ \\
\hline & $\mathrm{TP}(\mathrm{g} / 100 \mathrm{ml})$ & $77.35 \pm 5.44^{\mathrm{a}}$ & $62.50 \pm 4.80^{\mathrm{b}}$ & $65.10 \pm 2.40^{\mathrm{b}}$ \\
\hline \multirow[t]{3}{*}{ Liver } & $\operatorname{ALT}(\mathrm{U} / \mathrm{L})$ & $116 \pm 5.66^{\mathrm{b}}$ & $138.5 \pm 3.53^{\mathrm{a}}$ & $118.0 \pm 2.82^{b}$ \\
\hline & $\operatorname{AST}(\mathrm{U} / \mathrm{L})$ & $106.0 \pm 5.66^{\mathrm{a}}$ & $82.5 \pm 7.78^{b}$ & $74.5 \pm 3.54^{\mathrm{b}}$ \\
\hline & $\mathrm{TP}(\mathrm{g} / 100 \mathrm{ml})$ & $32.9 \pm 2.70^{\mathrm{a}}$ & $32.9 \pm 0.00^{\mathrm{a}}$ & $13.55 \pm 2.70^{\mathrm{b}}$ \\
\hline \multirow[t]{4}{*}{ Kidney } & ALT(U/L) & $4.00 \pm 0.00^{\mathrm{b}}$ & $6.70 \pm .20^{\mathrm{a}}$ & $4.00 \pm 0.00^{\mathrm{b}}$ \\
\hline & $\operatorname{AST}(\mathrm{U} / \mathrm{L})$ & $100.50 \pm 2.12^{\mathrm{a}}$ & $96.00 \pm 0.00^{\mathrm{a}}$ & $33.00 \pm 5.90^{\mathrm{b}}$ \\
\hline & $\operatorname{ALP}(\mathrm{U} / \mathrm{L})$ & $2416.82 \pm 194.71^{\mathrm{a}}$ & $1471.69 \pm 13.77^{\mathrm{c}}$ & $1825.00 \pm 185.80^{\mathrm{b}}$ \\
\hline & $\mathrm{TP}(\mathrm{g} / 100 \mathrm{ml})$ & $18.67 \pm 1.10^{\mathrm{a}}$ & $15.50 \pm 0.30^{\mathrm{b}}$ & $10.65 \pm 1.34^{\mathrm{c}}$ \\
\hline
\end{tabular}

- Values are mean \pm standard deviation.

- $\quad$ Mean (s) with the same super script in each row are not significant different at $5 \%$ level of significance $(\mathrm{P}<0.05)$.

- $\quad$ ALT stands for Alanine Aminotransferase, AST for Aspariate Aminotransferase. ALP for Alkaline phosphatase and TP for Total Protein.

Table 4 shows the marker enzymes activities and total protein concentration in both liver and kidney as well as in the plasma. Marker enzymes are important biochemical tools for diagnosing damage to internal organs [35-37]. Under state of stress, damage to liver, kidney and other organs leads to the rupture of plasma membrane hence the release of enzyme from the cells. These enzymes may be liberated into the blood [38]. Determination of the activities of aminotransferase enzymes thus provides valuable confirmatory or suggestive evidence of damage to internal organs [36]. The elevation in the activity of either alanine or aspartate aminotransferase in the plasma complemented by decreased activity in the liver is often useful as an index of liver cell damage [39]. The significant reduction in liver activity of AST, as shown in Table 4, is therefore not suggestive of damage to the liver since it is not complemented by an increase in the plasma activity of the enzyme. Moreover, ALT is a more specific index of hepatic cell damage than AST because of its selective concentration in the liver tissue [40]. ALT, as evident in Table 4, presented a higher liver and plasma activities in animals fed with Shea butter relative to the control. Hence no damage to the liver can be alleged.

Alkaline phosphatase is a marker enzyme for the plasma membrane and endoplasmic reticulum of the renal tissue [35,41]. Damage to the kidney will therefore lead to a decreased renal ALP activity and consequently increase the plasma ALP activity. The observed decrease in renal ALP activity, shown in Table 4, is not confirmatory of damage to the kidney since it is not accompanied by a corresponding increase in plasma activity of the enzyme. However, the reduction in the kidney and plasma activities of ALP may be suggestive of reversible side effects of the substances which may inhibit some cardiovascular disease, platelet aggregation and phagocytosis [42].

The significant reduction in the total protein of rats fed with Shea butter as presented in Table 4 can be attributed to the presence of saponins in the oil. Saponins reduce protein digestibility by the formation of sparingly digestible saponin-protein complexes in the intestine $[43,44]$.

\section{Conclusion}

In conclusion, discoveries arising from this study affirm that Shea butter as a dietary source of lipid pose no threat to hepatic and renal functions and agree with previous study on the hypolipidemic and antihypercholesterolemic abilities of Shea butter, therefore jointly postulating the possibility that the cumulative effect of long term consumption of Shea butter could prove cardio-protective and help lower coronary heart disease.

\section{References}

[1] Alfred T. "Fats and Fatty Oils". Ullmann's Encyclopedia of Industrial Chemistry. Weinheim: Wiley-VCH. 2002

[2] Samuel H. American Shea Butter Institute hand book, 11.28 http://www.American_Shea institute.com/ 2005.

[3] Ndukwe I. G., Amupitan J.O. Isah Y. and Adegoke K. S. Phytochemical screening of the crude extract of the roots, stem bark and leaves of Vitallaria paradoxa (GAERTN. F). Afr $J$ Biotechnol 2007; 6(16) pp 1905-1909. 
[4] Pretaorius C. J. and Watt E. Purification and Identification of Active components of Carpobrotus edullis L. J. Enthnopharma 2001; 76: 87-91.

[5] Agbahungba G. and Depommier D. World Oil Seeds Chemistry, Technology and Utilization. Van Nostraud Rein Hold, New York. p.554, 1989.

[6] Soladoye M. O., Orhiere S. S. and Ibimode B. M. Ethanobotanical Study of two Indigenous Multipurpose Plants in the Guinea Savanna of Kwara State -Vitellaria paradoxa and Parkia biglobosa. Biennial Conference of Ecological Society of Nigeria. Forestry Research Institute, Ibadan. p.13, 1989.

[7] National Research Council. Lost Crops of Africa: Volume II: Vegetables. 2006 ISBN 978-0-309-10333-6.

[8] Akihisa T., Kojima N., Katoh N., Ichimura Y., Suzuki H., Fukatsu M., Maranz S. and Masters E. T. Triterpene alcohol and fatty acid composition of Shea nut from seven African countries. J Oleo Sci. 2010; 59(7): 351-360.

[9] Ogbonnaya C. and AdgidiziP. P. Evaluation of somePhysico-chemical properties of Shea butter (Butyrospermum paradoxum) related to its value for food and industrial utilization. Intl J Post Harv Technol \& Innov. 2008; 1(3) pp 320-326.

[10] Fold N. "A matter of good taste? Quality and the construction of standards for chocolate in the European Union. Cahiers d'Economieet Sociologie Rurales. 2000; 55/56: 92-110"

[11] Alander J. Shea Butter- a Multi Functional Ingredient for Food and Cosmetics. Lipid Technol. 2004; 16:202-205.

[12] Esuoso K.O., Lutz H., Bayer E. and Kutubuddin M. Unsaponifiable Lipid Constituents of Some Underutilized Tropical Seed Oils. J. Agric. Food Chem. 2000; 48: 231-234.

[13] Essengue S. B., Stechschulte D. and Olson N. The use of Shea butter as an Emollient for Eczema. J Allergy \& Clin Immunol. 2009; 123(2). Pp 145-148.

[14] Kanwaljit K. C., Ramon B., Rosalia A., Galina G. and Anna N. W. Shea butter contains no IgE-binding soluble proteins. Letter to the editor. J Allergy Clin Immunol. 2010; 127( 3) pp 680-682. doi:10.1016/j.jaci.2010.10.022.

[15] Masters E. T., Yidana J. A. and Lovett P. N. Reinforcing Sound Management through Trade: Shea Tree Products in Africa. Unasylva. 2004; 210: 46-52.

[16] Akinwale A., Modu S., Maisartu M.A., Zainab M. A. and Bilkisu U. M. A. Effect of Feeding Various Concentrations of Shea oil on Some Biochemical Parameters in Normal Albino Rat. Bull Environ Pharmacol \& Life Sc. 2012; 1(2), pp14 -17. URL: www.bepls.com Online ISSN 2277-1808.

[17] Steins E. A. and Meyers G. L. National cholesterol education programme: Recommendations for triglyceride measurements, Clin Chem. 1995; 41: 1421-1426.

[18] Friedewald W., Levy R. and Fredrickson D. ().Estimation of the concentration of low-density lipoprotein cholesterol in plasma, without use of the preparative ultra-centrifuge, Clin. Chem. 1972; 18: 499-502.

[19] Elizalde G. and Scalfani A. Fat appetite in rats: flavor preferences conditioned by nutritive and non-nutritive oil emulsions. Appetite. 1990; 15(3):189-197. PMID 2281949.

[20] Ackroff K., Vigorito M. and Sclafani A. Fat appetite in rats: the response of infant and adult rats to nutritive and non-nutritive oil emulsions. Appetite. 1990; 15(3):171-188.

[21] Jain K. S., Kathiravan M. K., Somani R. S., and Shishoo C. J. The biology and chemistry of hyperlipidemia. Bio. Med. Chem., 2007; 15: 4674-4699.

[22] Kinosian B., Glick H., Preiss L., and Puder K. L. Cholesterol and coronary heart disease: predicting risks in men by changes in levels and ratios. $J$ of Inves Med., 1995; 43:443-450.

[23] Panagiotakos D. B., Pitsavos C., Skoumas J., Chrysohoou C., Toutouza M., Stefanadis C. L. and Toutouza P. K. Importance of LDL/HDL cholesterol ratio as a predictor for coronary heart disease events in patients with heterozygous familial hypercholesterolemia: a 15-year follow-up (1987-2002). Curr Med Res Opin; 2003; 19(2): 89-94.

[24] Natarajan S., Glick H., Criqui M., Horowitz D., Lipsitz S. R., and Kinosian B. Cholesterol measures to identify and treat individuals at risk for coronary heart disease. Am J Prev Med., 2003; 25: 50-57.

[25] El-Mahmood A. M., Doughari J. H. and Ladan N. Antimicrobial screening of stem bark extracts of Vitellaria paradoxa against some enteric pathogenic microorganisms. Afr J Pharm Pharmacol 2008; 2(5). pp. 089-094.

[26] Das T. K., Banerjee D., Charkraborty D., Pakhira M. C., Shrivastava B. and Kuhad R. C. Saponin: Role in animal system. Vet. World. 2012; 5(4):248-254.

[27] Sidhu G. S. and Oakenfull D. G. A mechanism for the hypercholesterolemic effect of saponins. Br. J. Nutr. 2005; 55(3):643-649.

[28] Oakenfull D. G. and Sidhu G. S. Could saponins be useful treatment for hypercholesterolemia? Eur J Clin Nutri. 1990; 44: $79-88$

[29] Yuldasheva L. N., Carvalho E. B., Catanho T. J. and Krasilnikov O. V. Cholesterol-dependent haemolytic activity of Passiflora quadrangularis leaves. Braz. J. Med. Biol. Res. 2005; 38(7) 1061-1070.

[30] Matsuura M. Saponins in garlic as modifiers of the risk of cardiovascular disease. J Nutri. 2001; 131:1000S-1005S.

[31] Han L.K., Xu B.J., Kimura Y., Zheng Y.N. and Okuda H. Platycodiradix affects lipid metabolism in mice with high fat diet induced obesity. J Nutr. 2000; 130:2760-2764.

[32] Davrieux F., Allal F., Plombo G., Kelly B., Okulo J. B., Thiam M., Diallo O. B. and Bouvet J. M. Near infrared spectroscopy for High-Throughput characterization of Shea tree (Vitellaria paradoxa) nut fat profiles. J agric food chem. 2010; 58, 7811-7819.

[33] Pronczuk A., Khosla P. and Hayes K. C. Dietary myristic, palmitic, and linoleic acids modulate cholesterolemia in gerbils. Foster Biomedical Research Laboratory, Brandeis University, Waltham, Massachusetts 02254. FASEB J. 1994; 8(14):1191-200.

[34] Labat J. B., Martini M. C., Carr T. P., Elhard B. M., Olson B. A., Bergmann S. D., Slavin J. L., Hayes K. C. and Hassel C. A. Cholesterol-lowering effects of modified animal fats in postmenopausal women. University of Minnesota, Department of Food Science and Nutrition, St. Paul 55108-6099, USA. $J$ Am Coll Nutr. 1997; 16(6):570-7. 
[35] Akanji M. A., Olagoke O. A. and Oloyede O. B. Effect of chronic consumption of metabisulphite on the integrity of the kidney cellular system. Toxicol 1993; 81:173-179.

[36] Dufour D.R., Lott J. A., Nottle F. S. and Seff L.B. Diagnosis and monitoring of hepatic injury in performance characteristics of laboratory tests. Clin. Chem. 2000; 46: 2027-2049.

[37] Shahjahan M., Sabitha K. E., Mallika J. and Shyamala-Devi C. S. Effect of Solanumtrilobatum against carbon tetrachloride induced hepatic damage in albino rats. Indian J. Med. Res. 2004; 120: 194-198.

[38] Zikic R.V., Stajn A.S., Paulovic S.Z., Ogajanovic B.J. and Saicic Z.S. Activity of superoxide dismutase and catalase in Erythrocytes and plasma aminotransferases of goldfish exposed to Cadmium. Physio. Rev. 2001; 50:105-111.

[39] Paula H., Pedrosa L. M., Júnior V. J. R., Haraguchi F. K., Santos R. C. and Silva M. E. Effect of an Aqueous Extract of Annatto (Bixa orellana) Seeds on Lipid Profile and Biochemical Markers of Renal and Hepatic Function in Hypercholesterolemic Rats. Braz. Arch. Biol. Technol. 2009; 52(6): pp. 1373-1378.
[40] He G. and Aoyama Y. ().Effects of Adding Some Dietary Fibers to a Cystine Diet on the Activities of Liver Antioxidant Enzymes and Serum Enzymes in Rats. Biosci Biotechnol Biochem 2003; 67:617-621.

[41] Martin P. and Friedman L.S. ().Assessment of Liver Function and Diagnostic Studies. In: Hand Book of Liver Disease. Friedmann, L.S. and E.B. Keeffe (Eds.), Churchill Livingstone, Philadelphia, 1-14. 1992.

[42] Isaacs C. E., Litov R, Marie P. Thomas H. Addition of lipids to infant formula produces antiviral and antibacterial activity. $J$. Nutr. Biochem. 1992; 3: 304-308.

[43] Potter S. M., Jimenez-Flores R., Pollack J., Lone T. A. and Berber-Jimenez M.D. Protein saponin interaction and its influence on blood lipids. J Agri Food Chem. 1993; 41: 1287-1291.

[44] George F., Zohar K., Harinder P. S. and Klaus B. The biological action of saponins in animals systems: a review. Brit $J$ Nutr. 2002; 88: 587-605. 